\title{
EZH2 as a Potential Target for NAFLD Therapy
}

\author{
Hyun Jung Lim ${ }^{1,2}$ and Mirang Kim ${ }^{1,2}, *$ (D) \\ 1 Personalized Genomic Medicine Research Center, Korea Research Institute of Bioscience and \\ Biotechnology (KRIBB), Daejeon 34141, Korea; hjlim@kribb.re.kr \\ 2 Department of Functional Genomics, University of Science and Technology (UST), Daejeon 34113, Korea \\ * Correspondence: mirang@kribb.re.kr; Tel.: +82-42-879-8113
}

Received: 18 October 2020; Accepted: 14 November 2020; Published: 16 November 2020

\begin{abstract}
Non-alcoholic fatty liver disease (NAFLD) is a complex disease that is affected by genetic predisposition and epigenetic modification. Deregulation of epigenetic pathways is now recognized as a frequent event in NAFLD, and understanding the mechanistic roles of these epigenetic factors may lead to new strategies for NAFLD treatment. Enhancer of zeste homolog 2 (EZH2) catalyzes methylation on Lys 27 of histone H3, which leads to chromatin compaction and gene silencing. EZH2 regulates embryonic development and cell lineage determination and is related to many human diseases. Recent studies show that EZH2 has critical roles in liver development, homeostasis, and regeneration. Moreover, aberrant activation of EZH2 promotes NAFLD progression. Several EZH2 inhibitors have been developed and studied both in vitro and in clinical trials. In this review, we summarize our current understanding of the role of EZH2 in NAFLD and highlight its potential as a novel therapeutic target for NAFLD treatment.
\end{abstract}

Keywords: epigenetics; EZH2; NAFLD; NASH; liver fibrosis

\section{Introduction}

Non-alcoholic fatty liver disease (NAFLD) is the most common liver disease worldwide [1]. The worldwide prevalence of NAFLD is $\sim 25 \%$, and its incidence has increased dramatically with the global epidemic of obesity [2]. NAFLD pathogenesis has been described extensively [3]. Initial theories for the pathogenesis of NAFLD were based on a two-hit hypothesis. According to this hypothesis, hepatic accumulation of lipid (the first hit) increases the susceptibility of the liver to further insults mediated by second hits. These second hits, such as inflammatory cytokines, mitochondrial dysfunction, and oxidative stress, lead to steatohepatitis and fibrosis [4,5]. However, human NAFLD is more complicated with the involvement of multiple factors, and now a multiple-hit hypothesis has been accepted to explain the progression of NAFLD [6].

In 1980, the term NAFLD was first coined to describe fatty liver disease arising in the absence of significant alcohol intake [7]. However, the heterogeneity of NAFLD patients suggests the need for a more accurate term that can reflect pathogenesis and can help with patient classification for therapy. Recently, metabolic (dysfunction) associated fatty liver disease (MAFLD) was suggested as a more appropriate overarching term for NAFLD [8].

NAFLD has several stages in its progression that can lead to non-alcoholic fatty liver (NAFL), non-alcoholic steatohepatitis (NASH), cirrhosis, and even hepatocellular carcinoma (HCC) [9]. Whereas NAFL is a simple steatosis, NASH is characterized by cell injury, inflammation, and hepatocyte ballooning that may further progress to fibrosis, cirrhosis, and HCC. Although patients with NAFL have a similar life expectancy to that of the general population, those with NASH have an impaired survival, due primarily to cardiovascular and liver-related causes [10]. High-fat, high-sugar, and hypercaloric diets increase the risk of hepatic steatosis [11]. By contrast, weight loss achieved by caloric 
restriction reduces hepatic inflammation and fibrosis [12]. Current NAFLD management includes diet and lifestyle changes for weight loss, management of metabolic risk factors, and pharmacological treatment [13]. The purpose of these treatments is to prevent NAFLD-associated complications [14]. Currently, there are no FDA-approved therapies for NAFLD itself, highlighting the urgent need to find appropriate targets for NAFLD therapy [15]. Treatment of NAFLD is difficult because the progression of NAFLD is a multi-factorial process [16]. Recently, our understanding of these pathways has increased substantially, along with our ability to antagonize them, and the development of new drugs for NAFLD patients is actively underway.

Diet, lifestyle, and environmental and genetic factors can lead to insulin resistance (IR), obesity, and gut microbiome changes. IR is one of the main factors in the development of steatosis and NASH. IR increases hepatic de novo lipogenesis and increases the flux of fatty acids to the liver, with impaired inhibition of adipose tissue lipolysis [17]. The synthesis and accumulation of triglyceride and toxic levels of lipid metabolites lead to hepatic inflammation, which results from mitochondrial dysfunction through oxidative stress and endoplasmic reticulum stress through activation of the unfolded protein response [18]. Therefore, genetic or epigenetic factors affect hepatocyte fat content, enzymatic processes, and the liver inflammatory environment, thus leading to inflammation and fibrosis [6].

Epigenetic modifications are heritable (and yet also reversible) modifications of the genome that do not involve a change in the DNA sequence [19]. Various enzymes and other proteins are involved in epigenetic modifications [20]. Aberrant epigenetic changes can lead to inappropriate gene expression and can promote many chronic diseases including NAFLD. As epigenetic modifications are reversible, chromatin-modifying enzymes have emerged as promising targets for disease therapy. Recently, various drugs targeting epigenetic regulators have been developed and used in clinical trials as well as in preclinical studies [21]. Enhancer of zeste homolog 2 (EZH2) is a histone lysine methyltransferase that is involved in many human diseases, most of which are types of cancer [22]. Recent epigenetic studies revealed that EZH2 has important roles in liver homeostasis and NAFLD progression. In this review, we highlight EZH2 as a potential target for NAFLD therapy.

\section{Epigenetic Features of NAFLD}

\subsection{DNA Methylation in NAFLD}

NAFLD is a complicated disease associated with genetic and epigenetic factors [23]. Genetic variation in PNPLA3 is one of the common genetic risk factors of NAFLD [24]. PNPLA3 is a lipid droplet-associated protein that has hydrolase activity toward triglycerides and retinyl esters. The PNPLA3 I148M variant (rs738409 C>G) is associated with hepatic triglyceride accumulation, inflammation, and fibrosis. Multiple genome-wide association studies and epigenetic studies have been conducted during the past decade, which have enhanced our understanding of the genetic and epigenetic factors contributing to NAFLD progression. The focus of this review is on these epigenetic mechanisms.

Environmental factors such as diet, lifestyle, and the gut microbiome affect NAFLD progression by inducing aberrant epigenetic changes. Epigenetic alterations interact with genetic risk factors to determine an individual's overall risk for NAFLD [25]. Epigenetic changes are reversible and heritable modifications that do not involve changes in the DNA sequence. The main epigenetic mechanisms involve DNA methylation, histone modifications, and non-coding RNAs. DNA methylation is the covalent addition of a methyl group to cytosine, resulting in 5-methylcytosine. DNA methyltransferases (DNMT1, DNMT3A, and DNMT3B) catalyze this reaction. DNA methylation is a relatively stable epigenetic mechanism that can regulate gene expression patterns to establish cell identity [26]. Methylation of $\mathrm{CpG}$ dinucleotides in promoter regions typically inhibits transcription.

Translational studies on human livers have indicated that NAFLD is associated with abnormal DNA methylation [23,27]. Advanced NAFLD is associated with decreased methylation of tissue repair genes and increased methylation of metabolic pathway genes [27]. The NAFLD liver shows hypermethylation 
and down-regulation of genes involved in mitochondrial function, lipid metabolism, and oxidoreductase activity, whereas tumorigenesis-related genes are hypomethylated and up-regulated [28]. Interestingly, Ahrens et al. [29] demonstrated that NAFLD-specific methylation patterns were partially reversed after massive weight loss induced by bariatric surgery. Moreover, epigenetic states can vary from person to person depending on genetic background. For example, methylation of the PNPLA3 regulatory region is affected by the PNPLA3 rs738409 genotype [30], and methylation of FAD2 is associated with the FAD2 variant rs174616 [31]. To sum up, reprogramming of DNA methylation occurs during NAFLD progression and may be affected by an individual's genotype as well as by environmental factors.

\subsection{Histone Modifications in NAFLD}

Modification of the amino-terminal tail of histones, such as histone acetylation and histone methylation, can result in changes in the chromatin structure and gene expression. Accumulating evidence demonstrates that excess nutrition and metabolic pathways can trigger histone modification as well as DNA methylation through deregulation of epigenetic regulatory enzymes [32]. By using co-substrates supplied by the diet or generated through cell metabolism, epigenetic regulatory enzymes provide a potential association between nutrition, metabolism, and transcriptional regulation [32,33].

Histone acetylation is a highly reversible epigenetic modification and is usually associated with open chromatin and transcriptional activation. Acetylation of a histone increases its negative charge, thereby reducing the strength of its interaction with negatively charged DNA. Histone acetyltransferases (HATs) are "writers" of histone acetylation, whereas histone deacetylases (HDACs) are "erasers" that remove the acetyl group from an acetylated lysine residue [34].

HDACs are increased in chronic liver disease, and HDAC inhibitors have been reported to suppress hepatic stellate cell (HSC) activation and lead to the suppression of liver fibrosis [35,36]. Among HDACs, HDAC8 has a key role in NAFLD-associated HCC [37]. HDAC8 is directly up-regulated in dietary obesity models of NASH and HCC [37]. HDAC8 interacts with EZH2 to repress Wnt antagonists AXIN2, $N K D 1, P P P 2 R 2 B$, and PRICKLE1, leading to $\beta$-catenin activation and consequent cell proliferation via histone $\mathrm{H} 4$ deacetylation and trimethylation on Lys 27 of histone H3 (H3K27me3) [37].

The bromodomain and extra-terminal domain (BET) family proteins (BRD2, BRD3, BRD4, and BRDT) are "readers" of acetylated histone and non-histone proteins [38]. The BET family proteins modulate the promoter and enhancer activity of pro-inflammatory genes [39]. Small-molecule BET inhibitors have been developed in clinical and preclinical studies [40], and BET inhibition reverses fibrotic progression and prevents liver fibrosis in the NASH mouse models [41].

Histone methylation can occur at various sites in histone proteins, mainly on lysine and arginine residues. Histone methylation is controlled by multiple positive and negative modulators, which can activate or repress transcription [42]. Methylation of H3K4, H3K36, and H3K79 is often associated with transcriptional activation. By contrast, methylation of H3K9, H3K27, and H4K20 is associated with transcriptional repression. In addition, histone methylation can also influence DNA methylation and vice versa [32].

Histone methylation has an important role in NAFLD. The expression of specific histone lysine methyltransferases (KMTs) and demethylases (KDMs) is altered during NAFLD development [43]. Bricambert et al. [44] demonstrated that a histone demethylase, plant homeodomain finger 2 (Phf2) acts as a molecular checkpoint to prevent NAFLD progression by specifically erasing H3K9me2 (dimethylation on Lys 9 of H3) marks on the promoter of carbohydrate response element binding protein (ChREBP)-regulated genes during obesity. Moreover, histone methyltransferases such as MLL1 [45] and ASH1 [46] are also associated with liver fibrosis. In particular, there is growing evidence that EZH2 has a driving role in NAFLD [47]. 


\section{Role of $\mathrm{EZH} 2$ in the Liver}

\subsection{Polycomb Group (PcG) Protein EZH2}

PcG proteins are evolutionarily conserved epigenetic regulators that are involved in transcriptional silencing and maintaining cell identity [48]. PcG proteins are grouped into two complexes, polycomb repressive complex 1 (PRC1) and PRC2. PRC2 binds chromatin and catalyzes H3K27me3. H3K27me3 is then recognized by PRC1, which leads to chromatin compaction and gene silencing [49] (Figure 1). The repressive histone mark H3K27me3 is frequently found with the active histone mark H3K4me3 (trimethylation on Lys 4 of histone H3) in the promoters of genes involved in developmental regulation. These regions are referred to as "bivalent domains" and have been suggested to silence developmental genes while keeping them poised for activation during cellular differentiation [50]. The human PRC2 contains suppressor of zeste 12 (SUZ12), embryonic ectoderm development (EED), and the enzymatic catalytic subunit EZH1 or EZH2 [51]. EZH2 is highly expressed in proliferating cells, whereas EZH1 is more abundant in non-dividing adult organs (such as kidney, brain, and skeletal muscle tissue) and has lower enzymatic activity [52].

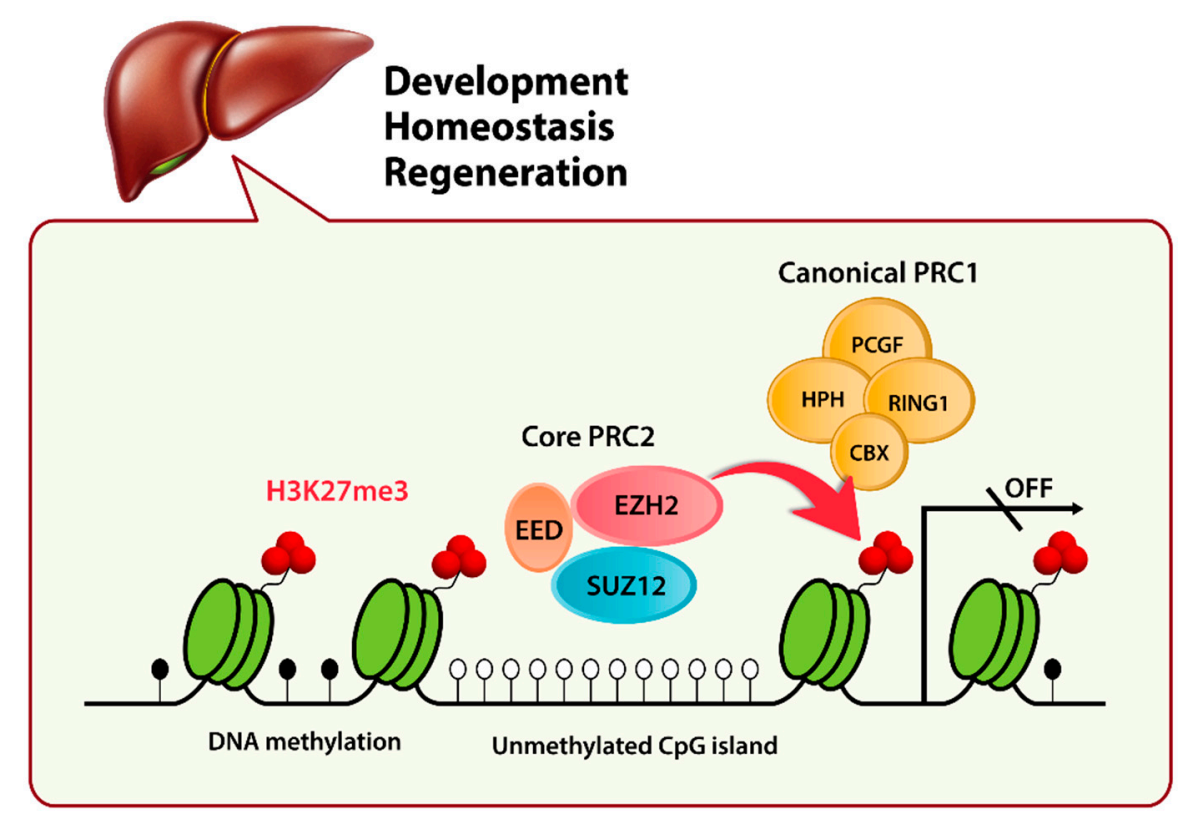

Figure 1. Role of EZH2 in the liver. The core polycomb repressive complex 2 (PRC2) contains suppressor of zeste 12 (SUZ12), embryonic ectoderm development (EED), and the enzymatic catalytic subunit EZH2. PRC2 is recruited to unmethylated $\mathrm{CpG}$ islands in repressed genes. EZH2 catalyzes trimethylation on Lys 27 of histone H3 (H3K27me3). H3K27me3 can act as a docking site for the chromobox domain (CBX) protein subunits of PRC1, which leads to chromatin compaction and gene silencing. Canonical PRC1 components include the ubiquitin ligase ring finger protein RING1 and other subunits, such as the human polyhomeotic homolog (HPH) and the polycomb group ring finger protein (PCGF). EZH2 has critical roles in liver development, homeostasis, and regeneration.

As a catalytic subunit of PRC2, EZH2 is mainly known as a histone lysine methyltransferase, but it can also methylate non-histone proteins such as transcription factors involved in cell adhesion and migration [53], cell growth and apoptosis [54], actin polymerization [55], or T-cell development [56]. In addition, EZH2 can function as a transcriptional activator in a polycomb-independent manner [57]. EZH2 has important roles in embryonic development and cell lineage determination [58] and is a key player in the cell cycle [59], autophagy, and apoptosis [60]. Therefore, EZH2 is related to many human diseases, including NAFLD, as well as cancer [22]. 


\subsection{EZH2 in Liver Cell Differentiation and Liver Homeostasis}

The liver has a tremendous ability to regenerate after partial resection and chemical injury [61]. The mechanism of liver regeneration depends on the proliferation of existing hepatocytes, homing of bone marrow cells, and the proliferation and differentiation of hepatic progenitor cells [62]. Hepatic progenitor cells actively proliferate in the fetal mouse liver and are the main source of parenchymal cells [63]. EZH2 has a key role in the proliferation and differentiation of hepatic progenitor cells [64]. EZH2 is highly expressed in hepatic progenitor cells and controls their expansion [65]. Deletion of the SET domain of EZH2 in fetal mouse liver results in a significant reduction in the total liver size and in the inhibition of hepatocyte differentiation [65]. Moreover, double knockout of EZH1 and EZH2 in mouse hepatocytes causes a decreased level of $\mathrm{H} 3 \mathrm{~K} 27 \mathrm{me} 3$ in the promoter of genes associated with hepatocyte homeostasis and regeneration [66]. Grindheim et al. [67] suggested that EZH2 controls the timing of postnatal hepatocyte maturation. Liver-specific disruption of EZH1 and EZH2 leads to immature differentiation of perinatal hepatocytes by prematurely activating the genes with bivalent domains in hepatocytes. These bivalent domain-containing genes are involved in regulating hepatocyte maturation and liver fibrosis [67]. Therefore, EZH2 has critical roles in liver development, homeostasis, and regeneration (Figure 1).

\section{EZH2 as a Therapeutic Target in NAFLD}

EZH2 overexpression is frequently detected in HCC, and the mechanisms by which EZH2 promotes HCC are associated with tumor growth and metastasis [68,69]. Specifically, EZH2 silences tumor-suppressor microRNAs [70,71] and regulates the cell cycle, proliferation, and apoptosis [72].

Recently, the role of EZH2 in NAFLD progression has begun to be revealed. Mann et al. [73] have described liver fibrosis as being epigenetically regulated by methyl-CpG binding protein 2 (MeCP2) and EZH2. Transdifferentiation of HSCs into myofibroblasts is a key event in liver fibrosis, and this event is suppressed by peroxisome proliferator-activated receptor-gamma (PPAR $\gamma$ ) [74]. During transdifferentiation, MeCP2 is recruited to the $5^{\prime}$ end of PPAR $\gamma$ and stimulates EZH2 expression. EZH2 methylates $\mathrm{H} 3 \mathrm{~K} 27$ to form a repressive chromatin structure in the $3^{\prime}$ exons of PPAR $\gamma$ resulting in down-regulation of PPAR $\gamma$ [73]. Moreover, EZH2 is up-regulated in the liver of $\mathrm{CCl}_{4}$-treated rats and promotes hepatic fibrosis by repressing the Wnt pathway antagonist Dkk-1 [75]. In addition, activation of the NAD-dependent deacetylase SIRT1 attenuates liver fibrosis through deacetylation of EZH2, which affects the stability of EZH2 and prevents myofibroblast generation [76].

Transforming growth factor $\beta$ (TGF- $\beta$ ) is one of the most important cytokines expressed after liver damage [77]. TGF- $\beta$ is increased in human hepatic fibrosis [78]. Up-regulation of TGF- $\beta$ in activated HSCs occurs through multiple mechanisms [79]. Martin-Mateos et al. [80] demonstrated that TGF- $\beta$-mediated HSC activation depends on the level of EZH2. EZH2 suppression results in attenuation of TGF- $\beta$-induced activation of the major fibrogenic genes such as FN1, COL1A1, and ASMA in human primary HSCs [80]. Moreover, EZH2 overexpression promotes TGF- $\beta$-mediated HSC activation in vitro. Furthermore, administration of the EZH2 inhibitor GSK-503 attenuates liver fibrosis in $\mathrm{CCl}_{4}$-treated or bile duct ligation mouse models [80]. Therefore, EZH2 modulation could be a potential target for hepatic fibrosis treatment. By contrast, negative effects related to a decrease in EZH2 function in NAFLD have also been suggested. Vella et al. [81] showed that EZH2 is down-regulated both in livers from NAFLD rats and in HepG2 cells treated with free fatty acid. In these free fatty acid-treated HepG2 cells, treatment with 3-deazaneplanocin A (DZNep), an EZH2 inhibitor (see Section 5.1), induces lipid accumulation. These opposing effects might be related to differences in NAFLD models. In addition, DZNep indirectly inhibits various S-adenosyl-L-methionine (SAM)-dependent methyltransferases as well as EZH2, which also prevents a straightforward interpretation of these findings.

More recently, Lee et al. [82] showed that EZH2 has a critical role in liver inflammation and fibrosis using the STAM NASH mouse model. In the STAM NASH mouse model, streptozotocin is administered, which causes inflammation and insulin secretion impairment, resulting in a phenotype resembling advanced type 2 diabetes [83]. STAM NASH mice serve as a model of human NAFLD, 
from steatosis to fibrosis, with a phenotype similar to that of human clinical samples [84]. Treatment of STAM NASH mice with the EZH2 inhibitor EPZ-6438 or UNC1999 decreases the mRNA expression of inflammatory cytokines and fibrosis markers [82]. To sum up, overexpression of EZH2 may drive NAFLD progression, and pharmacologic inhibition of EZH2 could be a promising strategy for treating NAFLD (Figure 2).

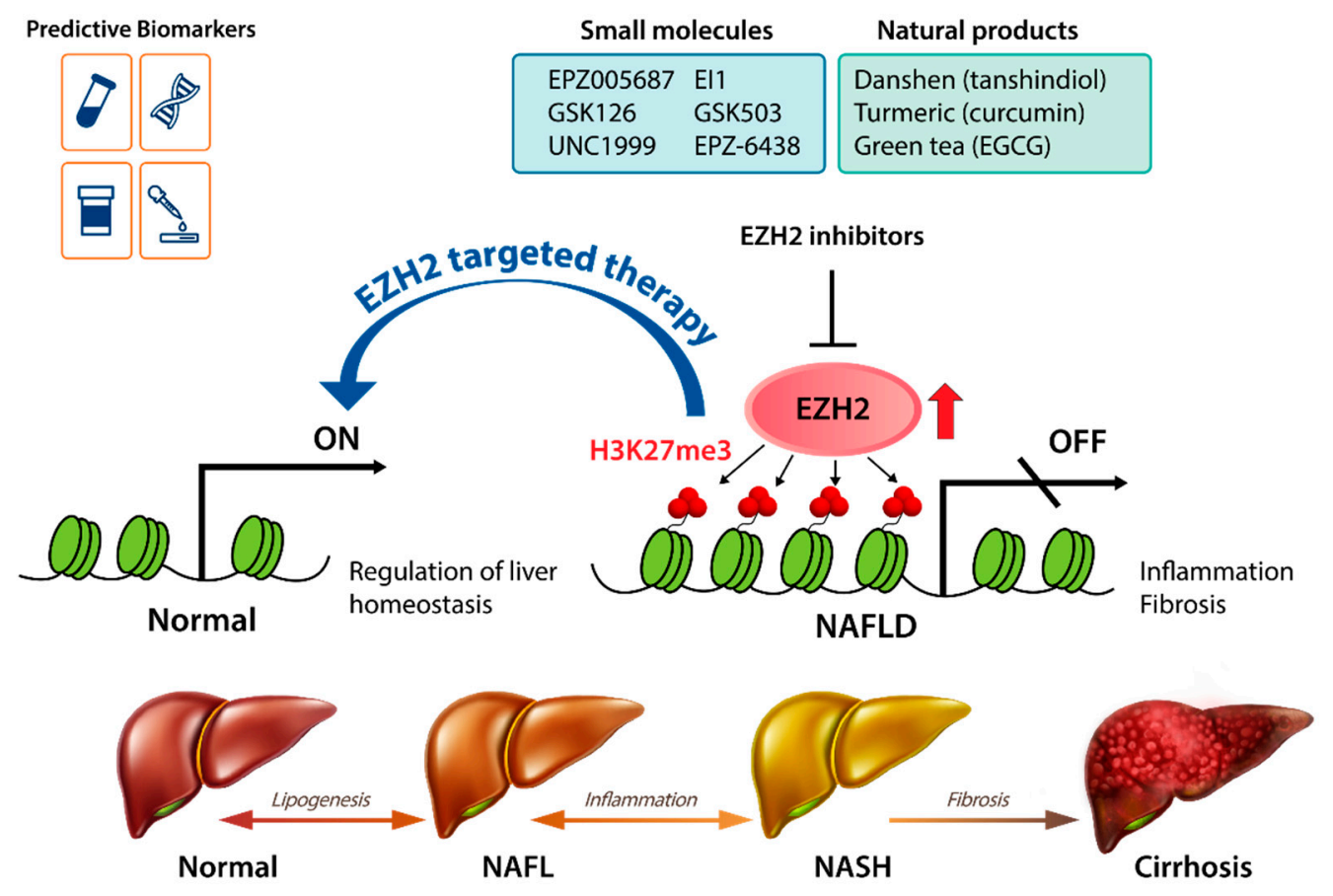

Figure 2. EZH2 as a therapeutic target in NAFLD. Abnormal activation of EZH2 may drive NAFLD progression, and EZH2-targeted therapy could be a promising strategy for NAFLD. A major class of small-molecule inhibitors of EZH2 is the SAM-competitive inhibitors, such as EPZ005687, EI1, GSK126, UNC1999, GSK503, and EPZ-6438. Natural products such as tanshindiols (the major active components of danshen), curcumin (a natural polyphenol from turmeric), and epigallocatechin-3-gallate (EGCG, the major chemical constituent of green tea) have EZH2-inhibiting activity. Development of predictive biomarkers to select patients suitable for EZH2-targeted therapy will improve the efficiency of this approach.

\section{EZH2 Inhibitors}

\subsection{Small-Molecule Inhibitors of EZH2}

Many pharmaceutical companies have developed EZH2 inhibitors in light of evidence that EZH2 can be a driver of human diseases including cancer [22]. SAM is a universal methyl donor for catalytic reactions of histone methyltransferases. A major class of EZH2 inhibitors is the SAM-competitive inhibitors, such as EPZ005687, EI1, GSK126, UNC1999, GSK503, and EPZ-6438 (Table 1).

DZNep is one of the purine nucleoside analogs, many of which are effective in the treatment of hematological malignancies and autoimmune disorders [85]. DZNep can inhibit EZH2 indirectly by interfering with SAM and SAH (S-adenosyl-L-homocysteine) metabolism, acting as an SAH hydrolase inhibitor [86]. Zeybel et al. [87] discovered that DZNep treatment inhibits liver fibrosis that results from multiple histone methylation modifications. They demonstrated that the in vivo modulation of HSC histone methylation is sufficient to suppress liver fibrosis by selectively targeting DZNep to HSC-derived myofibroblasts in the mouse [87]. This discovery represents an important proof of concept for epigenetic treatments targeting NAFLD. 
EPZ005687 is a selective inhibitor of EZH2 and displays $>500$-fold selectivity for EZH2 as compared with 15 other human protein methyltransferases and 50-fold selectivity over EZH1. It directly inhibits enzymatic activity of EZH2 rather than formation of PRC2 in an in vitro assay [88]. EI1 is another EZH2 inhibitor that directly binds to the enzyme and competes with the methyl group donor SAM. EI1-treated cells exhibit genome-wide loss of H3K27 methylation and activation of PRC2 target genes [89].

The selectivity of GSK126 for EZH2 is $>1000$-fold higher than its selectivity for 20 other human methyltransferases, and it is 150-fold more selective for EZH2 than for EZH1 [90]. GSK126 ameliorates disease severity in liver failure mice and down-regulates circulating and hepatic proinflammatory cytokines, especially TNF, by reducing H3K27me3 [91]. UNC1999, an analog of GSK126, shows a 10-fold selectivity for EZH2/EZH1. UNC1999 is highly selective for EZH2 and EZH1 over a broad range of epigenetic and non-epigenetic targets [92].

EPZ-6438 (Tazemetostat) shows a 35 -fold selectivity versus EZH1 and $>4500$-fold selectivity relative to 14 other histone methyltransferases [93]. EPZ-6438 was developed from EPZ005687 with improved pharmacokinetic properties including good oral bioavailability $[93,94]$. EPZ-6438 received approval in January 2020 in the USA for the treatment of epithelioid sarcoma. The recommended dosage regimen is $800 \mathrm{mg}$ twice daily, administered orally with or without food, until disease progression or unacceptable toxicity occurs. EPZ-6438 is also undergoing clinical development in various countries worldwide for use in several other tumor types, including diffuse large B-cell lymphoma and mesothelioma [95].

Table 1. Small molecules with EZH2-inhibiting activity.

\begin{tabular}{|c|c|c|c|}
\hline Compound & Mechanism & Selectivity * & Ref(s). \\
\hline DZNep & SAH hydrolase inhibitor & Unknown & {$[86,96]$} \\
\hline EPZ005687 & $\begin{array}{l}\text { SAM-competitive } \\
\text { inhibitor of PRC2 }\end{array}$ & $\begin{array}{c}>500 \text {-fold over other HMTs, } \\
\sim 50 \text {-fold over EZH1 }\end{array}$ & [88] \\
\hline EI1 & $\begin{array}{l}\text { SAM-competitive } \\
\text { inhibitor of PRC2 }\end{array}$ & $\begin{array}{c}>10,000 \text {-fold over other HMTs, } \\
\sim 90 \text {-fold over EZH1 }\end{array}$ & [89] \\
\hline GSK126 & $\begin{array}{l}\text { SAM-competitive } \\
\text { inhibitor of PRC2 }\end{array}$ & $\begin{array}{l}\text { >1000-fold over other HMTs, } \\
\text { 150-fold over EZH1 }\end{array}$ & [90] \\
\hline UNC1999 & $\begin{array}{l}\text { SAM-competitive } \\
\text { inhibitor of PRC2 }\end{array}$ & $\begin{array}{l}\text { 10,000-fold over other HMTs, } \\
\text { 10-fold over EZH1 }\end{array}$ & [92] \\
\hline GSK503 & $\begin{array}{l}\text { SAM-competitive } \\
\text { inhibitor of PRC2 }\end{array}$ & $\begin{array}{l}\text { >4000-fold over other HMTs, } \\
\text { 200-fold over EZH1 }\end{array}$ & [97] \\
\hline EPZ-6438 & $\begin{array}{l}\text { SAM-competitive } \\
\text { inhibitor of PRC2 }\end{array}$ & $\begin{array}{l}>4500 \text {-fold over other HMTs, } \\
\text { 35-fold over EZH1 }\end{array}$ & {$[93,94]$} \\
\hline
\end{tabular}

* Selectivity data are presented relative to inhibition of other HMTs (histone methyl transferases) and EZH1.

\subsection{Natural Products with EZH2-Inhibiting Activity}

With respect to safe alternative approaches for treating NAFLD, we are also interested in natural products that have EZH2-inhibiting activity. Shahabipour et al. [98] summarized various natural products that suppress EZH2.

The root of danshen (Salvia miltiorrhiza) has significant pharmacological activities with respect to a variety of human diseases. Clinical trials using danshen for the treatment of liver cirrhosis have suggested that danshen may promote the curative efficacy of treatments for liver cirrhosis [99]. Woo et al. [100] found that tanshindiols, the major active components of danshen, function as a SAM-competitive inhibitor and can inhibit EZH2 histone methyltransferase activity.

Turmeric (rhizomes of Curcuma longa) has been widely used not only as a culinary spice but also as a medicinal agent in Eastern medicine [101]. Curcumin, a natural polyphenol from turmeric, has been widely studied for its anti-inflammatory, anti-angiogenic, anti-oxidant, wound healing, and 
anti-cancer effects [102]. A clinical trial of curcumin for patients with NAFLD showed a significant reduction in liver fat content; body mass index; and serum levels of total cholesterol, low-density lipoprotein cholesterol, triglycerides, aspartate aminotransferase, alanine aminotransferase, glucose, and glycated hemoglobin as compared with the placebo group [103]. Moreover, curcumin was safe and well tolerated during the course of the trial [103]. Curcumin was found to suppress EZH2 expression through the MAPK pathway in breast cancer cells [104] and through let-7c and miR-101 in lung cancer cells [105].

Green tea (Camellia sinensis) is popular worldwide. Mansour-Ghanaei et al. [106] found significant effects of green tea supplementation on NAFLD treatment through the meta-analysis of clinical trials. Epigallocatechin-3-gallate (EGCG), the major chemical constituent of green tea, suppresses EZH2 expression in skin cancer cells [107] and causes anti-cancerous epigenetic changes in acute promyelocytic leukemia cells [108]. In summary, the properties of these natural compounds that relate to NAFLD treatment might be at least in part mediated by EZH2-suppressing activity. These natural products have the advantages of being safe and of having multi-target action, such that they could be used as nutraceuticals in combination with other NAFLD agents that do not have overlapping toxicity [98].

\section{Conclusions}

EZH2 has a key role in liver development and homeostasis, and abnormal activation of EZH2 can lead to NAFLD progression (Figure 2). Recent in vitro and in vivo studies have shown the therapeutic effects of EZH2 inhibitors in NAFLD, but our understanding of the molecular mechanisms involved is still limited. Further research is necessary to prove the direct relationship between EZH2 inhibition and NAFLD improvement. More accurate models that better mimic the NAFLD disease spectrum will provide increased mechanistic understanding [109]. Recent human liver organoid models made up of multiple cell types may facilitate the discovery of effective new drugs for NAFLD therapy $[110,111]$. Determining the detailed actions of EZH2 in the pathogenesis and progression of NAFLD should lead to new strategies to reverse this disease.

Several small molecules have been developed as EZH2 inhibitors. Encouragingly, EPZ-6438 was clinically approved for the treatment of epithelioid sarcoma and may be approved for the treatment of other diseases in the future. Peptides such as SAH-EZH2 (stabilized alpha-helix of EZH2) [112] and antisense oligonucleotides [113] can also inhibit EZH2. In addition, some natural products show EZH2-inhibiting effects.

To develop an EZH2 inhibitor as a drug for NAFLD treatment, low toxicity and high efficacy are required. Combination therapy with other treatments such as chemotherapy, immunotherapy, or microbiome therapy could have a synergistic effect if there are no overlapping toxicities. Importantly, the development of predictive biomarkers to select patients suitable for EZH2-targeted therapy will improve the efficiency of this approach [114]. Moreover, non-invasive biomarkers are urgently needed in NAFLD therapy. Recent genomic and epigenomic studies of liver tissue samples, blood, and feces from NAFLD patients should facilitate the development of future NAFLD treatments.

Author Contributions: Conceptualization, H.J.L. and M.K.; writing-original draft preparation, H.J.L. and M.K.; writing-review and editing, M.K.; funding acquisition, M.K. Both authors have read and agreed to the published version of the manuscript.

Funding: This research was funded by the National Research Foundation (NRF) of Korea, grant number NRF-2019R1A2C1087104, and the KRIBB research initiative grant.

Conflicts of Interest: The authors declare no conflict of interest. 


\section{Abbreviations}

$\begin{array}{ll}\text { BET } & \text { Bromodomain and extra-terminal domain } \\ \text { CBX } & \text { Chromobox domain } \\ \text { ChREBP } & \text { Carbohydrate response element binding protein } \\ \text { DNMT } & \text { DNA methyltransferase } \\ \text { DZNep } & \text { 3-deazaneplanocin A } \\ \text { EED } & \text { Embryonic ectoderm development } \\ \text { EGCG } & \text { Epigallocatechin-3-gallate } \\ \text { EZH2 } & \text { Enhancer of zeste homolog 2 } \\ \text { H3K27me3 } & \text { Trimethylation on Lys 27 of histone H3 } \\ \text { H3K4me3 } & \text { Trimethylation on Lys 27 of histone H3 } \\ \text { H3K9me2 } & \text { Dimethylation on Lys 9 of H3 } \\ \text { HAT } & \text { Histone acetyltransferase } \\ \text { HCC } & \text { Hepatocellular carcinoma } \\ \text { HDAC } & \text { Histone deacetylase } \\ \text { HMT } & \text { Histone methyl transferase } \\ \text { HPH } & \text { Human polyhomeotic homolog } \\ \text { HSC } & \text { Hepatic stellate cell } \\ \text { KDM } & \text { Histone lysine demethylase } \\ \text { KMT } & \text { Histone lysine methyltransferase } \\ \text { MeCP2 } & \text { Methyl-CpG binding protein 2 } \\ \text { NASH } & \text { Non-alcoholic steatohepatitis } \\ \text { PPAR } \gamma & \text { Peroxisome proliferator-activated receptor-gamma } \\ \text { PCG } & \text { Polycomb group } \\ \text { PCGF } & \text { Polycomb group ring finger protein } \\ \text { Phf2 } & \text { Plant homeodomain finger 2 } \\ \text { PRC } & \text { Polycomb repressive complex } \\ \text { SAH } & \text { S-adenosyl-L-homocysteine } \\ \text { SAM } & \text { S-adenosyl-L-methionine } \\ \text { SUZ12 } & \text { Suppressor of zeste 12 } \\ & \end{array}$

\section{References}

1. Cotter, T.G.; Rinella, M. Nonalcoholic fatty liver disease 2020: The state of the disease. Gastroenterology 2020, 158, 1851-1864. [CrossRef]

2. Swinburn, B.A.; Sacks, G.; Hall, K.D.; McPherson, K.; Finegood, D.T.; Moodie, M.L.; Gortmaker, S.L. The global obesity pandemic: Shaped by global drivers and local environments. Lancet 2011, 378, 804-814. [CrossRef]

3. Dowman, J.K.; Tomlinson, J.W.; Newsome, P.N. Pathogenesis of non-alcoholic fatty liver disease. QJM 2010, 103, 71-83. [CrossRef] [PubMed]

4. Day, C.P.; James, O.F. Steatohepatitis: A tale of two "hits"? Gastroenterology 1998, 114, 842-845. [CrossRef]

5. Day, C.P. From fat to inflammation. Gastroenterology 2006, 130, 207-210. [CrossRef] [PubMed]

6. Buzzetti, E.; Pinzani, M.; Tsochatzis, E.A. The multiple-hit pathogenesis of non-alcoholic fatty liver disease (NAFLD). Metabolism 2016, 65, 1038-1048. [CrossRef] [PubMed]

7. Ludwig, J.; Viggiano, T.R.; McGill, D.B.; Oh, B.J. Nonalcoholic steatohepatitis: Mayo clinic experiences with a hitherto unnamed disease. Mayo. Clin. Proc. 1980, 55, 434-438. [PubMed]

8. Eslam, M.; Sanyal, A.J.; George, J.; International Consensus, P. MAFLD: A consensus-driven proposed nomenclature for metabolic associated fatty liver disease. Gastroenterology 2020, 158, 1999-2014.e1991. [CrossRef]

9. Adams, L.A.; Lymp, J.F.; St Sauver, J.; Sanderson, S.O.; Lindor, K.D.; Feldstein, A.; Angulo, P. The natural history of nonalcoholic fatty liver disease: A population-based cohort study. Gastroenterology 2005, 129, 113-121. [CrossRef]

10. Fassio, E.; Alvarez, E.; Dominguez, N.; Landeira, G.; Longo, C. Natural history of nonalcoholic steatohepatitis: A longitudinal study of repeat liver biopsies. Hepatology 2004, 40, 820-826. [CrossRef] 
11. Koopman, K.E.; Caan, M.W.; Nederveen, A.J.; Pels, A.; Ackermans, M.T.; Fliers, E.; la Fleur, S.E.; Serlie, M.J. Hypercaloric diets with increased meal frequency, but not meal size, increase intrahepatic triglycerides: A randomized controlled trial. Hepatology 2014, 60, 545-553. [CrossRef] [PubMed]

12. Vilar-Gomez, E.; Martinez-Perez, Y.; Calzadilla-Bertot, L.; Torres-Gonzalez, A.; Gra-Oramas, B.; Gonzalez-Fabian, L.; Friedman, S.L.; Diago, M.; Romero-Gomez, M. Weight loss through lifestyle modification significantly reduces features of nonalcoholic steatohepatitis. Gastroenterology 2015, 149, 367-378. [CrossRef] [PubMed]

13. Pydyn, N.; Miekus, K.; Jura, J.; Kotlinowski, J. New therapeutic strategies in nonalcoholic fatty liver disease: A focus on promising drugs for nonalcoholic steatohepatitis. Pharmacol. Rep. 2020, 72, 1-12. [CrossRef] [PubMed]

14. Munteanu, M.A.; Nagy, G.A.; Mircea, P.A. Current management of NAFLD. Clujul. Med. 2016, 89, $19-23$. [CrossRef] [PubMed]

15. Oseini, A.M.; Sanyal, A.J. Therapies in non-alcoholic steatohepatitis (NASH). Liver Int. 2017, 37 (Suppl. 1), 97-103. [CrossRef] [PubMed]

16. Musso, G.; Cassader, M.; Gambino, R. Non-alcoholic steatohepatitis: Emerging molecular targets and therapeutic strategies. Nat. Rev. Drug Discov. 2016, 15, 249-274. [CrossRef] [PubMed]

17. Bugianesi, E.; Moscatiello, S.; Ciaravella, M.F.; Marchesini, G. Insulin resistance in nonalcoholic fatty liver disease. Curr. Pharm. Des. 2010, 16, 1941-1951. [CrossRef]

18. Mendez-Sanchez, N.; Cruz-Ramon, V.C.; Ramirez-Perez, O.L.; Hwang, J.P.; Barranco-Fragoso, B.; Cordova-Gallardo, J. New aspects of lipotoxicity in nonalcoholic steatohepatitis. Int. J. Mol. Sci. 2018, 19, 2034. [CrossRef]

19. Bird, A. Perceptions of epigenetics. Nature 2007, 447, 396-398. [CrossRef]

20. Egger, G.; Liang, G.; Aparicio, A.; Jones, P.A. Epigenetics in human disease and prospects for epigenetic therapy. Nature 2004, 429, 457-463. [CrossRef]

21. Lu, Y.; Chan, Y.T.; Tan, H.Y.; Li, S.; Wang, N.; Feng, Y. Epigenetic regulation in human cancer: The potential role of epi-drug in cancer therapy. Mol. Cancer 2020, 19, 79. [CrossRef] [PubMed]

22. Kim, K.H.; Roberts, C.W. Targeting EZH2 in cancer. Nat. Med. 2016, 22, 128-134. [CrossRef] [PubMed]

23. Eslam, M.; Valenti, L.; Romeo, S. Genetics and epigenetics of NAFLD and NASH: Clinical impact. J. Hepatol. 2018, 68, 268-279. [CrossRef] [PubMed]

24. Romeo, S.; Kozlitina, J.; Xing, C.; Pertsemlidis, A.; Cox, D.; Pennacchio, L.A.; Boerwinkle, E.; Cohen, J.C.; Hobbs, H.H. Genetic variation in PNPLA3 confers susceptibility to nonalcoholic fatty liver disease. Nat. Genet. 2008, 40, 1461-1465. [CrossRef] [PubMed]

25. Del Campo, J.A.; Gallego-Duran, R.; Gallego, P.; Grande, L. Genetic and epigenetic regulation in nonalcoholic fatty liver disease (NAFLD). Int. J. Mol. Sci. 2018, 19, 911. [CrossRef] [PubMed]

26. Kim, M. DNA methylation: A cause and consequence of type 2 diabetes. Genom. Inform. 2019, 17 , e38. [CrossRef] [PubMed]

27. Murphy, S.K.; Yang, H.; Moylan, C.A.; Pang, H.; Dellinger, A.; Abdelmalek, M.F.; Garrett, M.E.; Ashley-Koch, A.; Suzuki, A.; Tillmann, H.L.; et al. Relationship between methylome and transcriptome in patients with nonalcoholic fatty liver disease. Gastroenterology 2013, 145, 1076-1087. [CrossRef]

28. Hotta, K.; Kitamoto, T.; Kitamoto, A.; Ogawa, Y.; Honda, Y.; Kessoku, T.; Yoneda, M.; Imajo, K.; Tomeno, W.; Saito, S.; et al. Identification of the genomic region under epigenetic regulation during non-alcoholic fatty liver disease progression. Hepatol. Res. 2018, 48, E320-E334. [CrossRef] [PubMed]

29. Ahrens, M.; Ammerpohl, O.; von Schonfels, W.; Kolarova, J.; Bens, S.; Itzel, T.; Teufel, A.; Herrmann, A.; Brosch, M.; Hinrichsen, H.; et al. DNA methylation analysis in nonalcoholic fatty liver disease suggests distinct disease-specific and remodeling signatures after bariatric surgery. Cell Metab. 2013, 18, $296-302$. [CrossRef]

30. Kitamoto, T.; Kitamoto, A.; Ogawa, Y.; Honda, Y.; Imajo, K.; Saito, S.; Yoneda, M.; Nakamura, T.; Nakajima, A.; Hotta, K. Targeted-bisulfite sequence analysis of the methylation of CpG islands in genes encoding PNPLA3, SAMM50, and PARVB of patients with non-alcoholic fatty liver disease. J. Hepatol. 2015, 63, 494-502. [CrossRef]

31. Walle, P.; Mannisto, V.; de Mello, V.D.; Vaittinen, M.; Perfilyev, A.; Hanhineva, K.; Ling, C.; Pihlajamaki, J. Liver DNA methylation of FADS2 associates with FADS2 genotype. Clin. Epigenet. 2019, 11, 10. [CrossRef] [PubMed] 
32. Kaelin, W.G., Jr.; McKnight, S.L. Influence of metabolism on epigenetics and disease. Cell 2013, 153, 56-69. [CrossRef] [PubMed]

33. Lu, C.; Thompson, C.B. Metabolic regulation of epigenetics. Cell Metab. 2012, 16, 9-17. [CrossRef] [PubMed]

34. Seto, E.; Yoshida, M. Erasers of histone acetylation: The histone deacetylase enzymes. Cold Spring Harb. Perspect. Biol. 2014, 6, a018713. [CrossRef] [PubMed]

35. Niki, T.; Rombouts, K.; De Bleser, P.; De Smet, K.; Rogiers, V.; Schuppan, D.; Yoshida, M.; Gabbiani, G.; Geerts, A. A histone deacetylase inhibitor, trichostatin a, suppresses myofibroblastic differentiation of rat hepatic stellate cells in primary culture. Hepatology 1999, 29, 858-867. [CrossRef]

36. Park, K.C.; Park, J.H.; Jeon, J.Y.; Kim, S.Y.; Kim, J.M.; Lim, C.Y.; Lee, T.H.; Kim, H.K.; Lee, H.G.; Kim, S.M.; et al. A new histone deacetylase inhibitor improves liver fibrosis in BDL rats through suppression of hepatic stellate cells. Br. J. Pharmacol. 2014, 171, 4820-4830. [CrossRef]

37. Tian, Y.; Wong, V.W.; Wong, G.L.; Yang, W.; Sun, H.; Shen, J.; Tong, J.H.; Go, M.Y.; Cheung, Y.S.; Lai, P.B.; et al. Histone deacetylase HDAC8 promotes insulin resistance and beta-catenin activation in NAFLD-associated hepatocellular carcinoma. Cancer Res. 2015, 75, 4803-4816. [CrossRef]

38. Dhalluin, C.; Carlson, J.E.; Zeng, L.; He, C.; Aggarwal, A.K.; Zhou, M.M. Structure and ligand of a histone acetyltransferase bromodomain. Nature 1999, 399, 491-496. [CrossRef]

39. Belkina, A.C.; Denis, G.V. BET domain co-regulators in obesity, inflammation and cancer. Nat. Rev. Cancer 2012, 12, 465-477. [CrossRef]

40. Theodoulou, N.H.; Tomkinson, N.C.; Prinjha, R.K.; Humphreys, P.G. Clinical progress and pharmacology of small molecule bromodomain inhibitors. Curr. Opin. Chem. Biol. 2016, 33, 58-66. [CrossRef]

41. Ding, N.; Hah, N.; Yu, R.T.; Sherman, M.H.; Benner, C.; Leblanc, M.; He, M.; Liddle, C.; Downes, M.; Evans, R.M. BRD4 is a novel therapeutic target for liver fibrosis. Proc. Natl. Acad. Sci. USA 2015, 112, 15713-15718. [CrossRef]

42. Jambhekar, A.; Dhall, A.; Shi, Y. Roles and regulation of histone methylation in animal development. Nat. Rev. Mol. Cell Biol. 2019, 20, 625-641. [CrossRef]

43. Klose, R.J.; Kallin, E.M.; Zhang, Y. JmjC-domain-containing proteins and histone demethylation. Nat. Rev. Genet. 2006, 7, 715-727. [CrossRef] [PubMed]

44. Bricambert, J.; Alves-Guerra, M.C.; Esteves, P.; Prip-Buus, C.; Bertrand-Michel, J.; Guillou, H.; Chang, C.J.; Vander Wal, M.N.; Canonne-Hergaux, F.; Mathurin, P.; et al. The histone demethylase Phf2 acts as a molecular checkpoint to prevent NAFLD progression during obesity. Nat. Commun. 2018, 9, 2092. [CrossRef] [PubMed]

45. Page, A.; Paoli, P.P.; Hill, S.J.; Howarth, R.; Wu, R.; Kweon, S.M.; French, J.; White, S.; Tsukamoto, H.; Mann, D.A.; et al. Alcohol directly stimulates epigenetic modifications in hepatic stellate cells. J. Hepatol. 2015, 62, 388-397. [CrossRef] [PubMed]

46. Perugorria, M.J.; Wilson, C.L.; Zeybel, M.; Walsh, M.; Amin, S.; Robinson, S.; White, S.A.; Burt, A.D.; Oakley, F.; Tsukamoto, H.; et al. Histone methyltransferase ash1 orchestrates fibrogenic gene transcription during myofibroblast transdifferentiation. Hepatology 2012, 56, 1129-1139. [CrossRef] [PubMed]

47. Argemi, J.; Bataller, R. Identifying new epigenetic drivers of liver fibrosis. Cell Mol. Gastroenterol. Hepatol. 2019, 7, 237-238. [CrossRef]

48. Ringrose, L.; Paro, R. Epigenetic regulation of cellular memory by the polycomb and trithorax group proteins. Ann. Rev. Genet. 2004, 38, 413-443. [CrossRef] [PubMed]

49. Francis, N.J.; Kingston, R.E.; Woodcock, C.L. Chromatin compaction by a polycomb group protein complex. Science 2004, 306, 1574-1577. [CrossRef]

50. Bernstein, B.E.; Mikkelsen, T.S.; Xie, X.; Kamal, M.; Huebert, D.J.; Cuff, J.; Fry, B.; Meissner, A.; Wernig, M.; Plath, K.; et al. A bivalent chromatin structure marks key developmental genes in embryonic stem cells. Cell 2006, 125, 315-326. [CrossRef]

51. Di Croce, L.; Helin, K. Transcriptional regulation by polycomb group proteins. Nat. Struct. Mol. Biol. 2013, 20, 1147-1155. [CrossRef] [PubMed]

52. Margueron, R.; Li, G.; Sarma, K.; Blais, A.; Zavadil, J.; Woodcock, C.L.; Dynlacht, B.D.; Reinberg, D. Ezh1 and Ezh2 maintain repressive chromatin through different mechanisms. Mol. Cell 2008, 32, 503-518. [CrossRef] [PubMed]

53. Gunawan, M.; Venkatesan, N.; Loh, J.T.; Wong, J.F.; Berger, H.; Neo, W.H.; Li, L.Y.; La Win, M.K.; Yau, Y.H.; Guo, T.; et al. The methyltransferase Ezh2 controls cell adhesion and migration through direct methylation of the extranuclear regulatory protein talin. Nat. Immunol. 2015, 16, 505-516. [CrossRef] 
54. Kim, E.; Kim, M.; Woo, D.H.; Shin, Y.; Shin, J.; Chang, N.; Oh, Y.T.; Kim, H.; Rheey, J.; Nakano, I.; et al. Phosphorylation of EZH2 activates STAT3 signaling via stat3 methylation and promotes tumorigenicity of glioblastoma stem-like cells. Cancer Cell 2013, 23, 839-852. [CrossRef] [PubMed]

55. Su, I.H.; Dobenecker, M.W.; Dickinson, E.; Oser, M.; Basavaraj, A.; Marqueron, R.; Viale, A.; Reinberg, D.; Wulfing, C.; Tarakhovsky, A. Polycomb group protein Ezh2 controls actin polymerization and cell signaling. Cell 2005, 121, 425-436. [CrossRef]

56. Vasanthakumar, A.; Xu, D.; Lun, A.T.; Kueh, A.J.; van Gisbergen, K.P.; Iannarella, N.; Li, X.; Yu, L.; Wang, D.; Williams, B.R.; et al. A non-canonical function of Ezh2 preserves immune homeostasis. EMBO Rep. 2017, 18, 619-631. [CrossRef] [PubMed]

57. Xu, K.; Wu, Z.J.; Groner, A.C.; He, H.H.; Cai, C.; Lis, R.T.; Wu, X.; Stack, E.C.; Loda, M.; Liu, T.; et al. EZH2 oncogenic activity in castration-resistant prostate cancer cells is polycomb-independent. Science 2012, 338, 1465-1469. [CrossRef]

58. Batool, A.; Jin, C.; Liu, Y.X. Role of EZH2 in cell lineage determination and relative signaling pathways. Front. Biosci. 2019, 24, 947-960. [CrossRef]

59. Hu, X.; Eastman, A.E.; Guo, S. Cell cycle dynamics in the reprogramming of cellular identity. FEBS Lett. 2019, 593, 2840-2852. [CrossRef]

60. Yao, Y.; Hu, H.; Yang, Y.; Zhou, G.; Shang, Z.; Yang, X.; Sun, K.; Zhan, S.; Yu, Z.; Li, P.; et al. Downregulation of enhancer of zeste homolog 2 (EZH2) is essential for the induction of autophagy and apoptosis in colorectal cancer cells. Genes 2016, 7, 83. [CrossRef]

61. Michalopoulos, G.K.; DeFrances, M.C. Liver regeneration. Science 1997, 276, 60-66. [CrossRef] [PubMed]

62. Fausto, N. Liver regeneration and repair: Hepatocytes, progenitor cells, and stem cells. Hepatology 2004, 39, 1477-1487. [CrossRef] [PubMed]

63. Fausto, N.; Campbell, J.S.; Riehle, K.J. Liver regeneration. Hepatology 2006, 43, S45-S53. [CrossRef] [PubMed]

64. Aoki, R.; Chiba, T.; Miyagi, S.; Negishi, M.; Konuma, T.; Taniguchi, H.; Ogawa, M.; Yokosuka, O.; Iwama, A. The polycomb group gene product Ezh2 regulates proliferation and differentiation of murine hepatic stem/progenitor cells. J. Hepatol. 2010, 52, 854-863. [CrossRef] [PubMed]

65. Koike, H.; Ouchi, R.; Ueno, Y.; Nakata, S.; Obana, Y.; Sekine, K.; Zheng, Y.W.; Takebe, T.; Isono, K.; Koseki, H.; et al. Polycomb group protein Ezh2 regulates hepatic progenitor cell proliferation and differentiation in murine embryonic liver. PLoS ONE 2014, 9, e104776. [CrossRef]

66. Bae, W.K.; Kang, K.; Yu, J.H.; Yoo, K.H.; Factor, V.M.; Kaji, K.; Matter, M.; Thorgeirsson, S.; Hennighausen, L. The methyltransferases enhancer of zeste homolog (EZH) 1 and EZH2 control hepatocyte homeostasis and regeneration. FASEB J. 2015, 29, 1653-1662. [CrossRef]

67. Grindheim, J.M.; Nicetto, D.; Donahue, G.; Zaret, K.S. Polycomb repressive complex 2 proteins EZH1 and EZH2 regulate timing of postnatal hepatocyte maturation and fibrosis by repressing genes with euchromatic promoters in mice. Gastroenterology 2019, 156, 1834-1848. [CrossRef]

68. Cai, M.Y.; Tong, Z.T.; Zheng, F.; Liao, Y.J.; Wang, Y.; Rao, H.L.; Chen, Y.C.; Wu, Q.L.; Liu, Y.H.; Guan, X.Y.; et al. EZH2 protein: A promising immunomarker for the detection of hepatocellular carcinomas in liver needle biopsies. Gut 2011, 60, 967-976. [CrossRef]

69. Au, S.L.; Wong, C.C.; Lee, J.M.; Fan, D.N.; Tsang, F.H.; Ng, I.O.; Wong, C.M. Enhancer of zeste homolog 2 epigenetically silences multiple tumor suppressor micrornas to promote liver cancer metastasis. Hepatology 2012, 56, 622-631. [CrossRef]

70. Chen, S.; Pu, J.; Bai, J.; Yin, Y.; Wu, K.; Wang, J.; Shuai, X.; Gao, J.; Tao, K.; Wang, G.; et al. EZH2 promotes hepatocellular carcinoma progression through modulating miR-22/galectin-9 axis. J. Exp. Clin. Cancer Res. 2018, 37, 3. [CrossRef]

71. Liu, H.; Liu, Y.; Liu, W.; Zhang, W.; Xu, J. EZH2-mediated loss of miR-622 determines cxcr4 activation in hepatocellular carcinoma. Nat. Commun. 2015, 6, 8494. [CrossRef] [PubMed]

72. Feng, H.; Yu, Z.; Tian, Y.; Lee, Y.Y.; Li, M.S.; Go, M.Y.; Cheung, Y.S.; Lai, P.B.; Chan, A.M.; To, K.F.; et al. A CCRK-EZH2 epigenetic circuitry drives hepatocarcinogenesis and associates with tumor recurrence and poor survival of patients. J. Hepatol. 2015, 62, 1100-1111. [CrossRef] [PubMed]

73. Mann, J.; Chu, D.C.; Maxwell, A.; Oakley, F.; Zhu, N.L.; Tsukamoto, H.; Mann, D.A. MeCP2 controls an epigenetic pathway that promotes myofibroblast transdifferentiation and fibrosis. Gastroenterology 2010, 138, 705-714, 714.e1-4. [CrossRef] [PubMed] 
74. Hazra, S.; Xiong, S.; Wang, J.; Rippe, R.A.; Krishna, V.; Chatterjee, K.; Tsukamoto, H. Peroxisome proliferator-activated receptor gamma induces a phenotypic switch from activated to quiescent hepatic stellate cells. J. Biol. Chem. 2004, 279, 11392-11401. [CrossRef]

75. Yang, Y.; Chen, X.X.; Li, W.X.; Wu, X.Q.; Huang, C.; Xie, J.; Zhao, Y.X.; Meng, X.M.; Li, J. EZH2-mediated repression of Dkk1 promotes hepatic stellate cell activation and hepatic fibrosis. J. Cell Mol. Med. 2017, 21, 2317-2328. [CrossRef] [PubMed]

76. Zhao, H.; Wang, Z.; Tang, F.; Zhao, Y.; Feng, D.; Li, Y.; Hu, Y.; Wang, C.; Zhou, J.; Tian, X.; et al. Carnosol-mediated Sirtuin 1 activation inhibits Enhancer of Zeste Homolog 2 to attenuate liver fibrosis. Pharmacol. Res. 2018, 128, 327-337. [CrossRef] [PubMed]

77. Dooley, S.; ten Dijke, P. Tgf-beta in progression of liver disease. Cell Tissue Res. 2012, 347, 245-256. [CrossRef] [PubMed]

78. Castilla, A.; Prieto, J.; Fausto, N. Transforming growth factors beta 1 and alpha in chronic liver disease. Effects of interferon alfa therapy. N. Engl. J. Med. 1991, 324, 933-940. [CrossRef]

79. Friedman, S.L. Hepatic stellate cells: Protean, multifunctional, and enigmatic cells of the liver. Physiol. Rev. 2008, 88, 125-172. [CrossRef]

80. Martin-Mateos, R.; De Assuncao, T.M.; Arab, J.P.; Jalan-Sakrikar, N.; Yaqoob, U.; Greuter, T.; Verma, V.K.; Mathison, A.J.; Cao, S.; Lomberk, G.; et al. Enhancer of zeste homologue 2 inhibition attenuates TGF-beta dependent hepatic stellate cell activation and liver fibrosis. Cell Mol. Gastroenterol. Hepatol. 2019, 7, 197-209. [CrossRef]

81. Vella, S.; Gnani, D.; Crudele, A.; Ceccarelli, S.; De Stefanis, C.; Gaspari, S.; Nobili, V.; Locatelli, F.; Marquez, V.E.; Rota, R.; et al. EZH2 down-regulation exacerbates lipid accumulation and inflammation in in vitro and in vivo NAFLD. Int. J. Mol. Sci. 2013, 14, 24154-24168. [CrossRef] [PubMed]

82. Lee, S.; Woo, D.C.; Kang, J.; Ra, M.; Kim, K.H.; Lee, S.R.; Choi, D.K.; Lee, H.; Hong, K.B.; Min, S.H.; et al. The role of the histone methyltransferase EZH2 in liver inflammation and fibrosis in STAM NASH mice. Biology 2020, 9, 93. [CrossRef] [PubMed]

83. Furman, B.L. Streptozotocin-induced diabetic models in mice and rats. Curr. Protoc. Pharmacol. 2015, 70, 5.47.1-5.47.20. [CrossRef] [PubMed]

84. Saito, K.; Uebanso, T.; Maekawa, K.; Ishikawa, M.; Taguchi, R.; Nammo, T.; Nishimaki-Mogami, T.; Udagawa, H.; Fujii, M.; Shibazaki, Y.; et al. Characterization of hepatic lipid profiles in a mouse model with nonalcoholic steatohepatitis and subsequent fibrosis. Sci. Rep. 2015, 5, 12466. [CrossRef]

85. Tam, E.K.; Nguyen, T.M.; Lim, C.Z.; Lee, P.L.; Li, Z.; Jiang, X.; Santhanakrishnan, S.; Tan, T.W.; Goh, Y.L.; Wong, S.Y.; et al. 3-deazaneplanocin a and neplanocin a analogues and their effects on apoptotic cell death. ChemMedChem 2015, 10, 173-182. [CrossRef]

86. Fujiwara, T.; Saitoh, H.; Inoue, A.; Kobayashi, M.; Okitsu, Y.; Katsuoka, Y.; Fukuhara, N.; Onishi, Y.; Ishizawa, K.; Ichinohasama, R.; et al. 3-deazaneplanocin a (DZNep), an inhibitor of s-adenosylmethionine-dependent methyltransferase, promotes erythroid differentiation. J. Biol. Chem. 2014, 289, 8121-8134. [CrossRef]

87. Zeybel, M.; Luli, S.; Sabater, L.; Hardy, T.; Oakley, F.; Leslie, J.; Page, A.; Moran Salvador, E.; Sharkey, V.; Tsukamoto, H.; et al. A proof-of-concept for epigenetic therapy of tissue fibrosis: Inhibition of liver fibrosis progression by 3-deazaneplanocin a. Mol. Ther. 2017, 25, 218-231. [CrossRef]

88. Knutson, S.K.; Wigle, T.J.; Warholic, N.M.; Sneeringer, C.J.; Allain, C.J.; Klaus, C.R.; Sacks, J.D.; Raimondi, A.; Majer, C.R.; Song, J.; et al. A selective inhibitor of EZH2 blocks H3K27 methylation and kills mutant lymphoma cells. Nat. Chem. Biol. 2012, 8, 890-896. [CrossRef]

89. Qi, W.; Chan, H.; Teng, L.; Li, L.; Chuai, S.; Zhang, R.; Zeng, J.; Li, M.; Fan, H.; Lin, Y.; et al. Selective inhibition of Ezh2 by a small molecule inhibitor blocks tumor cells proliferation. Proc. Natl. Acad. Sci. USA 2012, 109, 21360-21365. [CrossRef]

90. McCabe, M.T.; Ott, H.M.; Ganji, G.; Korenchuk, S.; Thompson, C.; Van Aller, G.S.; Liu, Y.; Graves, A.P.; Della Pietra, A., 3rd; Diaz, E.; et al. EZH2 inhibition as a therapeutic strategy for lymphoma with EZH2-activating mutations. Nature 2012, 492, 108-112. [CrossRef]

91. Zhou, T.; Sun, Y.; Li, M.; Ding, Y.; Yin, R.; Li, Z.; Xie, Q.; Bao, S.; Cai, W. Enhancer of zeste homolog 2-catalysed H3K27 trimethylation plays a key role in acute-on-chronic liver failure via TNF-mediated pathway. Cell Death Dis. 2018, 9, 590. [CrossRef] [PubMed] 
92. Konze, K.D.; Ma, A.; Li, F.; Barsyte-Lovejoy, D.; Parton, T.; Macnevin, C.J.; Liu, F.; Gao, C.; Huang, X.P.; Kuznetsova, E.; et al. An orally bioavailable chemical probe of the lysine methyltransferases EZH2 and EZH1. ACS Chem. Biol. 2013, 8, 1324-1334. [CrossRef] [PubMed]

93. Knutson, S.K.; Warholic, N.M.; Wigle, T.J.; Klaus, C.R.; Allain, C.J.; Raimondi, A.; Porter Scott, M.; Chesworth, R.; Moyer, M.P.; Copeland, R.A.; et al. Durable tumor regression in genetically altered malignant rhabdoid tumors by inhibition of methyltransferase EZH2. Proc. Natl. Acad. Sci. USA 2013, 110, $7922-7927$. [CrossRef] [PubMed]

94. Knutson, S.K.; Kawano, S.; Minoshima, Y.; Warholic, N.M.; Huang, K.C.; Xiao, Y.; Kadowaki, T.; Uesugi, M.; Kuznetsov, G.; Kumar, N.; et al. Selective inhibition of EZH2 by EPZ-6438 leads to potent antitumor activity in ezh2-mutant non-hodgkin lymphoma. Mol. Cancer Ther. 2014, 13, 842-854. [CrossRef]

95. Hoy, S.M. Tazemetostat: First approval. Drugs 2020, 80, 513-521. [CrossRef] [PubMed]

96. Tan, J.; Yang, X.; Zhuang, L.; Jiang, X.; Chen, W.; Lee, P.L.; Karuturi, R.K.; Tan, P.B.; Liu, E.T.; Yu, Q. Pharmacologic disruption of polycomb-repressive complex 2-mediated gene repression selectively induces apoptosis in cancer cells. Genes Dev. 2007, 21, 1050-1063. [CrossRef] [PubMed]

97. Beguelin, W.; Popovic, R.; Teater, M.; Jiang, Y.; Bunting, K.L.; Rosen, M.; Shen, H.; Yang, S.N.; Wang, L.; Ezponda, T.; et al. EZH2 is required for germinal center formation and somatic EZH2 mutations promote lymphoid transformation. Cancer Cell 2013, 23, 677-692. [CrossRef]

98. Shahabipour, F.; Caraglia, M.; Majeed, M.; Derosa, G.; Maffioli, P.; Sahebkar, A. Naturally occurring anti-cancer agents targeting EZH2. Cancer Lett. 2017, 400, 325-335. [CrossRef]

99. Zhu, C.; Cao, H.; Zhou, X.; Dong, C.; Luo, J.; Zhang, C.; Liu, J.; Ling, Y. Meta-analysis of the clinical value of danshen injection and huangqi injection in liver cirrhosis. Evid. Based Complement. Alternat. Med. 2013, 2013, 842824. [CrossRef]

100. Woo, J.; Kim, H.Y.; Byun, B.J.; Chae, C.H.; Lee, J.Y.; Ryu, S.Y.; Park, W.K.; Cho, H.; Choi, G. Biological evaluation of tanshindiols as EZH2 histone methyltransferase inhibitors. Bioorg. Med. Chem. Lett. 2014, 24, 2486-2492. [CrossRef]

101. Shen, L.; Liu, C.C.; An, C.Y.; Ji, H.F. How does curcumin work with poor bioavailability? Clues from experimental and theoretical studies. Sci. Rep. 2016, 6, 20872. [CrossRef] [PubMed]

102. Maheshwari, R.K.; Singh, A.K.; Gaddipati, J.; Srimal, R.C. Multiple biological activities of curcumin: A short review. Life Sci. 2006, 78, 2081-2087. [CrossRef] [PubMed]

103. Rahmani, S.; Asgary, S.; Askari, G.; Keshvari, M.; Hatamipour, M.; Feizi, A.; Sahebkar, A. Treatment of non-alcoholic fatty liver disease with curcumin: A randomized placebo-controlled trial. Phytother. Res. 2016, 30, 1540-1548. [CrossRef] [PubMed]

104. Hua, W.F.; Fu, Y.S.; Liao, Y.J.; Xia, W.J.; Chen, Y.C.; Zeng, Y.X.; Kung, H.F.; Xie, D. Curcumin induces down-regulation of EZH2 expression through the MAPK pathway in MDA-MB-435 human breast cancer cells. Eur. J. Pharmacol. 2010, 637, 16-21. [CrossRef] [PubMed]

105. Wu, G.Q.; Chai, K.Q.; Zhu, X.M.; Jiang, H.; Wang, X.; Xue, Q.; Zheng, A.H.; Zhou, H.Y.; Chen, Y.; Chen, X.C.; et al. Anti-cancer effects of curcumin on lung cancer through the inhibition of EZH2 and NOTCH1. Oncotarget 2016, 7, 26535-26550. [CrossRef]

106. Mansour-Ghanaei, F.; Hadi, A.; Pourmasoumi, M.; Joukar, F.; Golpour, S.; Najafgholizadeh, A. Green tea as a safe alternative approach for nonalcoholic fatty liver treatment: A systematic review and meta-analysis of clinical trials. Phytother. Res. 2018, 32, 1876-1884. [CrossRef]

107. Shimizu, M.; Fukutomi, Y.; Ninomiya, M.; Nagura, K.; Kato, T.; Araki, H.; Suganuma, M.; Fujiki, H.; Moriwaki, H. Green tea extracts for the prevention of metachronous colorectal adenomas: A pilot study. Cancer Epidemiol. Biomark. Prev. 2008, 17, 3020-3025. [CrossRef]

108. Borutinskaite, V.; Virksaite, A.; Gudelyte, G.; Navakauskiene, R. Green tea polyphenol egcg causes anti-cancerous epigenetic modulations in acute promyelocytic leukemia cells. Leuk. Lymphoma 2018, 59, 469-478. [CrossRef]

109. Lau, J.K.; Zhang, X.; Yu, J. Animal models of non-alcoholic fatty liver disease: Current perspectives and recent advances. J. Pathol. 2017, 241, 36-44. [CrossRef]

110. Ouchi, R.; Togo, S.; Kimura, M.; Shinozawa, T.; Koido, M.; Koike, H.; Thompson, W.; Karns, R.A.; Mayhew, C.N.; McGrath, P.S.; et al. Modeling steatohepatitis in humans with pluripotent stem cell-derived organoids. Cell Metab. 2019, 30, 374-384.e376. [CrossRef] 
111. Mun, S.J.; Ryu, J.S.; Lee, M.O.; Son, Y.S.; Oh, S.J.; Cho, H.S.; Son, M.Y.; Kim, D.S.; Kim, S.J.; Yoo, H.J.; et al. Generation of expandable human pluripotent stem cell-derived hepatocyte-like liver organoids. J. Hepatol. 2019, 71, 970-985. [CrossRef] [PubMed]

112. Kim, W.; Bird, G.H.; Neff, T.; Guo, G.; Kerenyi, M.A.; Walensky, L.D.; Orkin, S.H. Targeted disruption of the EZH2-EED complex inhibits EZH2-dependent cancer. Nat. Chem. Biol. 2013, 9, 643-650. [CrossRef] [PubMed]

113. Xiao, L.; Tien, J.C.; Vo, J.; Tan, M.; Parolia, A.; Zhang, Y.; Wang, L.; Qiao, Y.; Shukla, S.; Wang, X.; et al. Epigenetic reprogramming with antisense oligonucleotides enhances the effectiveness of androgen receptor inhibition in castration-resistant prostate cancer. Cancer Res. 2018, 78, 5731-5740. [CrossRef] [PubMed]

114. Duan, R.; Du, W.; Guo, W. EZH2: A novel target for cancer treatment. J. Hematol. Oncol. 2020, $13,104$. [CrossRef]

Publisher's Note: MDPI stays neutral with regard to jurisdictional claims in published maps and institutional affiliations.

(C) 2020 by the authors. Licensee MDPI, Basel, Switzerland. This article is an open access article distributed under the terms and conditions of the Creative Commons Attribution (CC BY) license (http://creativecommons.org/licenses/by/4.0/). 